\title{
Bishop-Calabresi Report
}

National Cancer Institute

\section{Source}

National Cancer Institute. Bishop-Calabresi Report. NCI Thesaurus. Code C18659.

A report by the Ad Hoc Working Group of the National Cancer Advisory Board presented on June 9,1995 , outlining, in detail, the state of the intramural research program of the National Cancer Institute. The Ad Hoc Working Group was headed by J. Michael Bishop and Paul Calabresi. 